\section{Sanitation of Rural Areas in the Tropics}

Is a Chadwick public lecture, delivered on October 25, on the sanitation of rural areas in the tropics and sub-tropics with special reference to housing, Prof. D. B. Blacklock expressed the view that rural sanitation in tropical and sub-tropical dependencies and possessions is gravely neglected. He touched on the subject of hygienic conditions in rural West Africa, but attention was directed chiefly to the present state of rural India. The chief part of the leeture dealt with housing in the rural areas, and Prof. Blacklock emphasised by suitable illustrations how diseases of various kinds come to be associated with types of houses showing special defects. These defects are either of site, of structure and material, or dueto the habits of the inmates. A house-relation of many diseases in tropical and sub-tropical countries is directly traceable to an origin in such defects; the removal of the known defects would largely eliminate those house-diseases, which seriously affect millions of people. To-day we have at our disposal in the shape of broadcasting a valuable method of imparting the principles of village hygiene even to those who can neither read nor write. In addition to such educative methods, it is the duty of any Government which wishes to attain success in raising the standard of rural sanitation to undertake a further measure. This is the building, using local materials so far as is possible, of standard houses and villages at many accessible places in each province or even district as examples of hygienic construction. Demonstration villages kept up to the standard would exemplify to the villagers more vividly than other methods the dangerous defects of their own homes.

\section{Pathology at Leeds}

The Department of Pathology and Bacteriology, University of Leeds, has issued its annual report for 1933 by Profs. Stewart and McLeod, with some details of the research work in progress. This includes investigations on industrial lung diseases, namely, pulmonary fibrosis of hæmatite miners and asbestos workers, correlation of types of diphtheria bacilli with clinical severity of the cases, phenomena of bacterial respiration, bacterial hæmolysins, and industrial problems such as the bacterial purification of gas-works' effluents. A brief report by Prof. Passey on cancer research is also included.

\section{New British Birds}

ThE note under this heading in our "News and Views", October 27, p. 658, was prepared before the error in the original announcement by the British Ornithologists' Union became known. The Continental song thrush, renamed Turdus ericetorum planiceps in the July issue of Ibis, should now read Turdus ericetorum philomelus (Ibis, October).

\section{Marmite: Vitamin $B_{1}$ Content}

WiтH reference to the recent statement in our columns (NATURe, Oct. 20, p. 623) that the yeast extract "Marmite" contains 840 international vitamin
$B_{1}$ units per oz., Mr. A. R. Keast, 4 Anne Boleyn's Walk, Cheam, Surrey, writes that in answer to inquiries made some months ago, he was informed that this result had been obtained from an isolated sample furnished by the Marmite Food Extract Co. Ltd. Biological assays of ordinary Marmite carried out in Mr. Keast's own laboratories and elsewhere have never, apparently, yielded a result higher than 280 international units per oz. This figure, although high, is lower than the assayed content of certain other products on the market.

\section{Announcements}

Dr. Herbert Dingle, assistant professor of astrophysies in the Imperial College of Science and Technology, will deliver the Cantor Lectures of the Royal Society of Arts on November 19, 26 and December 3. His subject will be "Modern Spectroscopy".

The Onyx Oil and Chemical Co., 15 Exchange Place, Jersey City, N. J., has founded an industrial fellowship in the Mellon Institute of Industrial Research, Pittsburgh, Pa., to be held by Dr. Robert N. Wenzel, who is working on problems in textile processing and finishing. Dr. Wenzel is well known for his studies of fatty acids and related compounds.

IN connexion with the centenary celebrations at Melbourne, a temporary exhibition of drawings and maps commemorating Admiral Phillip, the first Governor of Australia, has been placed in a case in the Central Hall of the Natural History Museum. The thirteen sketches by Thomas Watling, a convict transported in 1792 for forgery, and other contemporary artists, show Sydney and Port Jackson as they were at the close of the eighteenth century, the arrival of the Governor in H.M.S. Sirius, aborigines, and the earliest known illustration of the Echidna. The maps of Norfolk Island and Port Jackson are of considerable interest. It was on Norfolk Island that Capt. James Cook, the discoverer of Australia, landed in 1774.

Applications are invited for the following appointments, on or before the dates mentioned :-A lecturer in electrical engineering at Rotherham College of Technology and Art-The Director of Education, Education Offices, Rotherham (Nov. 8). An assistant at the London Museum-The Keeper, London Museum, St. James's, S.W.1 (Nov. 17). A dean of the British Postgraduate Medical School-The Chairman of the Governing Body, British Postgraduate Medical School, New Public Office, Whitehall, London, S.W.1 (Nov. 17). An experimental officer for wireless research work in the War Department Establishment at Chatham-The Under-Secretary of State (C.5), The War Office, London, S.W.1 (Nov. 19). A Hackett professor of agriculture in the University of Western Australia_The Agent-General for Western Australia, 115 Strand, London, W.C.2 (Nov. 20). An understudy to the Deputy Director of Research of the British Cotton Industry Research AssociationThe Director of Research, Shirley Institute, Didsbury, Manchester. 